\title{
Bacterial pathogens associated with hand-dug wells in Ibadan city, Nigeria
}

\author{
Odeleye, F. O. ${ }^{1}$ and Idowu, A. O. ${ }^{2 *}$ \\ ${ }^{1}$ Department of Pharmaceutical Microbiology, Faculty of Pharmacy, Olabisi Onabanjo University, Sagamu, Nigeria. \\ ${ }^{2}$ Department of Pharmaceutics and Pharmaceutical Technology, Faculty of Pharmacy, University of Lagos, Nigeria.
}

Received 9 December, 2014; Accepted 9 February, 2015

\begin{abstract}
The supply of pipe borne water in Nigeria has over the years become grossly inadequate or totally nonexistent. This has led many people to seek alternative sources of water from streams, springs and especially hand-dug wells. This study was carried out to investigate the bacteriological quality of water from hand-dug wells in lbadan city. This was done by investigating bacterial indicator of water quality in samples collected from $\mathbf{5 0}$ hand-dug wells and three bore holes from five different local government areas within Ibadan Municipal city and examined for total coliform and faecal coliform. Water samples from $96 \%$ of the wells were found to be contaminated with both total coliform and faecal coliform. The total coliform counts and fecal coliform counts ranged between 0 to $160 \times 10^{3} / 100 \mathrm{ml}$ and 0 to $22 \times 10^{3} / 100$ $\mathrm{ml}$, respectively. The predominant bacterial isolates include Escherichia coli (38.5\%), Klebsiella spp. $(16.9 \%)$, Staphylococcus aureus (13.8\%) and Enterobacter spp. (9.2\%). While antibiotic susceptibility to nitrofurantoin (96.9\%), gentamycin $(93.6 \%)$ and streptomycin $(93.3 \%)$ was high, it was low in ampicillin $(37.8 \%)$ and to a lesser extent in Cotrimoxazole(66.7\%). $24.1 \%$ of the isolates were multidrug resistant with about seven patterns observed. Hand-dug wells in the area of study were highly contaminated with pathogenic bacteria and this exposes consumers of water drawn from these wells to the risk of contracting various waterborne diseases.
\end{abstract}

Key words: Bacterial pathogens, coliforms, hand dug well, water borne, disease.

\section{INTRODUCTION}

Water is indispensable to the human life for drinking and for domestic purposes. A decrease in the availability of fresh water is fast becoming a global problem especially in the developing nations due to urbanization, industrialization and rapid population growth. The reality is that as world population rapidly increases, necessitating an increase in demand for water, the amount available per person are getting smaller (Lamikanra, 1999).
About half of the Nigerian population is without access to potable water supply (NWSR, 2011). Apart from shortages in supply of potable water, absence of basic sanitary and hygiene practices has led to frequent outbreaks of water borne diseases with high incidences of morbidity and mortality. In many urban cities in Nigeria, pipe-borne water supply is grossly irregular or totally absent.

*Corresponding author. E-mail: Solaid2002@yahoo.com. Tel: 08027348864.

Author(s) agree that this article remains permanently open access under the terms of the Creative Commons Attribution License 4.0 International License 
In Ibadan, the largest city, West Coast of Africa, only about $22.6 \%$ of the population was being served by the municipal water system (ADB, 2008; Ince et al., 2010). This situation has led to many homes relying on alternative sources of water such as hand dug well to meet domestic needs. Most of the wells are poorly constructed due to poverty and lack of proper technology. Since there is really no formal guideline or regulations for the construction of wells in the city, it is not unexpected that water obtained from these wells will vary in quality. Contamination of ground water may be due to faulty well construction and improper well location (Osho and Fagade, 2000).

Besides, overcrowding, poor sanitary practices and the unhygienic methods of drawing water from wells exposes those who depend on wells for their domestic water source especially for drinking to health risks associated with consumption of non-potable water. The major source of water pollution is faecal matter of human or animal origin through which intestinal pathogens such as coliforms and faecal Streptococci gain entrance into the water. The consumption of untreated contaminated water can result in waterborne diseases, which include cholera, typhoid, amoebic and bacillary dysentery and other diarrhoeal diseases. The WHO estimates that waterrelated diseases are responsible for $80 \%$ of all illnesses and death in the developing world with 1.8 million deaths annually from water borne diseases; $90 \%$ being children less than 5 years old (Prüss-Üstün et al, 2008)

According to Nigeria Water Sector Roadmap (NWSR) an estimated 194,000 of children under 5 years old die annually in Nigeria due to cholera, diarrhoea and other related water borne diseases (NWSR, 2011). Results from studies carried out in different parts of the country (Akinyemi et al., 2006; Idowu et al., 2011; Odeyemi et al., 2011) show that water sources for domestic purposes have disturbing levels of microbial pollution and this has implications for the prevalence of waterborne diseases.

In order to meet the target $7 \mathrm{C}$ of the MDG and her long term development goals of becoming one of the top 20 economies by the year 2020, the government has identified improvement in adequate water supply and sanitation as key areas. According to the finding in a recent study, $63.74 \%$ of the population in Moniya, a suburb of Ibadan gets water from hang-dug well, $10.68 \%$ from pipe borne water and $25.58 \%$ from borehole suggesting that hand-dug well is the main source of water supply in the city (Owoeye, 2013). Since hand-dug well has become a major source of water supply in Ibadan municipality, it is necessary to carry out frequent evaluation of well water quality to investigate the health risk (in terms of microbial contamination by pathogens) to which the consumers are subjected with a view to formulate policies and design strategies that would improve its water quality.

The present study investigates the presence of coliforms and faecal streptococci in hand-dug wells in Ibadan city, Nigeria as well as the susceptibility of resulting bacterial isolates to commonly prescribed antibiotics.

\section{MATERIALS AND METHODS}

\section{Study sites}

Ibadan is located within the southwestern Nigeria between the coordinate $7^{\circ} 23^{\prime} 47^{\prime \prime} \mathrm{N}, 3^{\circ} 55^{\prime} 0^{\prime \prime} \mathrm{E}$. The capital city of Oyo State and the third largest metropolitan area by population in Nigeria after Lagos and Kano with a population of over 3 million, Ibadan is also the largest metropolitan geographical area located $128 \mathrm{~km}$ inland northeast of Lagos and $530 \mathrm{~km}$ southwest of Abuja, the federal capital. The principal inhabitants of the city are the Yorubas. Ibadan is densely populated with many unplanned neigbourhoods and is poorly drained leading to flooding during periods of heavy rains (Ajayi et al., 2012). Due to absence of sewage systems and sewage treatment facilities, untreated sewage are indiscriminately discharged into the environment. Dug wells are the main source of water in the study areas. To ensure geographical spread 5 zones based on the five local government areas within Ibadan municipality were selected as sampling areas. The local government areas are Ibadan North; Ibadan North-West; Ibadan North-East; Ibadan South-East; Ibadan South-West. The depth and the sanitary condition of the surrounding of each well were noted. Two methods of raising water from the wells by users were either by rope and bucket or pump (electric or hand-pump).

\section{Study design}

Water from a total of 50 dug wells randomly selected (10 from each local government area) geographically spread across five local government areas in Ibadan city and 3 bore holes were sampled and investigated for their bacteriological quality. The antibiotic susceptibility of the isolates was also determined to ascertain effective drugs that could be used for treatment of waterborne diseases.

\section{Sample collection}

Water samples were collected into $200 \mathrm{ml}$ bottles by dipping sterile bottle into the well with the aid of previously disinfected sinker and rope. Samples were stored in ice box immediately after collection and were processed in the laboratory within 1-2 $\mathrm{h}$ after collection.

\section{Bacteriological analysis}

\section{Determination of bacterial counts}

The standard plate count method was used to determine the total viable bacterial population. Nutrient agar was used as culture medium and colonies for total viable counts were counted using a Stuart scientific colony counter. The five tubes most probably number (MPN) technique (APHA, 2006) was used to estimate the coliform density. Differential tests were carried out in brilliant green lactose bile broth (BGLBB) incubated at $44^{\circ} \mathrm{C}$ for $18-24 \mathrm{~h}$.

\section{Isolation of bacteria}

Samples were inoculated onto nutrient agar, MacConkey agar, mannitol salt agar and eosine methylene blue (EMB) agar, and plates incubated at $37^{\circ} \mathrm{C}$ for $24 \mathrm{~h}$. Pure cultures were subjected to 
Table 1. Viable Bacterial Counts of well water samples.

\begin{tabular}{cccccc}
\hline \multirow{2}{*}{ Sample } & \multicolumn{5}{c}{ Total viable count cfu/ml x 10 } \\
\cline { 2 - 6 } & Ibadan North & Ibadan North-West & lbadan North-East & lbadan South-East & lbadan South- West \\
\hline 1 & 0.01 & 0.41 & ND & 0.66 & 0.05 \\
2 & 0.23 & 0.20 & ND & 0.10 & 0.30 \\
3 & 0.12 & 9.30 & ND & 0.05 & 0.27 \\
4 & 0.04 & 43.00 & ND & 0.23 & 6.50 \\
5 & 5.50 & 1.00 & ND & $0.02^{*}$ & 3.70 \\
6 & 2.10 & 54.00 & ND & 13.00 & $0.002^{*}$ \\
7 & 0.90 & 31.00 & ND & 1.10 & 0.21 \\
8 & 0.006 & 0.06 & ND & 0.60 & 1.50 \\
9 & 0.15 & 0.22 & ND & 1.20 & 1.40 \\
10 & 0.01 & 100 & ND & 4.00 & 0.20 \\
11 & 0.03 & - &
\end{tabular}

${ }^{*}$ Borehole sample; ND, not determined.

Table 2. Coliform count of well water samples.

\begin{tabular}{cccccc}
\hline \multirow{2}{*}{ Sample } & \multicolumn{5}{c}{ Total viable count cfu/ml x 10 } \\
\cline { 2 - 6 } & Ibadan North & Ibadan North-West & Ibadan North-East & Ibadan South-East & Ibadan South- West \\
\hline 1 & 0.28 & 9.00 & 17.00 & 16.00 & 0.07 \\
2 & 1.60 & 2.20 & 0.00 & 2.40 & 0.52 \\
3 & 1.60 & 5.00 & 0.70 & 0.70 & 0.13 \\
4 & 0.35 & 5.00 & 0.20 & 5.00 & 0.50 \\
5 & 16.00 & 16.00 & 0.22 & $0.00^{*}$ & 1.70 \\
6 & 0.04 & 50.00 & 0.04 & 16.00 & 1.10 \\
7 & 0.50 & 20.00 & 16.00 & 1.10 & $0.02^{*}$ \\
8 & 0.17 & 4.00 & 3.00 & 8.00 & 3.00 \\
9 & 5.00 & 30.00 & $0.00^{*}$ & 16.00 & 2.30 \\
10 & 2.40 & 50.00 & - & 160.00 & 0.20 \\
11 & 1.30 & - & - & 0.00 & 2.30 \\
\hline
\end{tabular}

${ }^{*}$ Borehole sample.

Gram staining, oxidase test, catalase test, motility test, coagulase test (for suspected Staphylococcus) and growth on Triple Sugar Iron (TSI) agar. Bacterial pathogens were then characterized by colonial growth on suitable media and standard biochemical tests as described by Cowan and Steel (1993)

\section{Antibiotic susceptibility testing (AST)}

The Kirby-Bauer agar disc diffusion technique was used to test the isolates for antibiotic sensitivity. Antibiotic discs tested were from Abtek Biological Ltd, Italy and included Colistin $(25 \mu \mathrm{g})$, nitrofuratoin $(200 \mu \mathrm{g})$, tetracyclines [tetracycline $(25 \mu \mathrm{g}), \beta$-lactams [ampicillin $(25 \mu \mathrm{g})$ folic acid synthesis inhibitor [cotrimoxazole $(25 \mu \mathrm{g})$ ], quinolone [nalidixic acid $(30 \mu \mathrm{g})$ ], aminoglycoside [gentamicin (10 $\mu \mathrm{g})$ ] and streptomycin $25(\mu \mathrm{g})$.

\section{RESULTS}

Water samples from the wells in the 5 Local government areas were grossly contaminated with bacterial pathogens.
The total viable counts ranged from 0.002 to $100 \times 10^{3}$ $\mathrm{cfu} / \mathrm{ml}$ (Table 1). There was no significant difference in counts between study locations $(p=0.073)$. The indicator organisms were totally absent in one well each from location 3 and 4 and 2 of the 3 boreholes. The total coliform counts ranged from 0 to $160 \times 10^{3} / 100 \mathrm{ml}$ (Table 2) while the faecal coliform counts ranged from 0 to $22 \times 10^{3} / 100 \mathrm{ml}$ (Table 3). WHO recommends total absence of coliform and fecal coliform in $100 \mathrm{ml}$ of drinking water (WHO, 2010).

While the difference in total coliform counts between the locations were not significant $(p=0.243)$ the fecal counts between the locations were significantly different $(p=0.03)$. Both total viable count and faecal coliform count were highest in location 2 (mean counts of $23.92 \times 10^{3}$ and $8.41 \times 10^{3}$ respectively) and lowest in location 5 (mean counts of $1.41 \times 10^{3}$ and $1.02 \times 10^{3}$ respectively), while the total coliform count was highest in location 4 (mean count of $22.52 \times 10^{3}$ ) and lowest in location 5 (Mean count of 
Table 3. Faecal Coliform count of well water samples.

\begin{tabular}{|c|c|c|c|c|c|}
\hline \multirow{2}{*}{ Sample } & \multicolumn{5}{|c|}{ Faecal Coliform count $/ 100 \mathrm{ml} \times 10^{3}$} \\
\hline & Ibadan North & Ibadan North-West & Ibadan North-East & Ibadan South-East & Ibadan South- West \\
\hline 1 & 0.14 & 9.00 & 17.00 & 9.00 & 0.02 \\
\hline 2 & 1.60 & 2.20 & 0.00 & 1.30 & 0.52 \\
\hline 3 & 0.23 & 0.70 & 0.70 & 0.70 & 0.08 \\
\hline 4 & 0.17 & 1.70 & 0.20 & 5.00 & 0.50 \\
\hline 5 & 1.70 & 3.50 & 0.14 & $0.00^{*}$ & 0.80 \\
\hline 6 & 0.04 & 22.00 & 0.04 & 16.00 & 1.10 \\
\hline 7 & 0.22 & 20.00 & 3.50 & 1.10 & $0.00^{*}$ \\
\hline 8 & 0.07 & 4.00 & 3.00 & 8.00 & 2.30 \\
\hline 9 & 2.20 & 8.00 & $0.00^{*}$ & 3.30 & 2.30 \\
\hline 10 & 2.40 & 13.00 & - & 22.00 & 0.20 \\
\hline 11 & 0.80 & - & - & 0.00 & 0.20 \\
\hline
\end{tabular}

*Borehole sample.

Table 4. Bacterial counts with respect to site.

\begin{tabular}{llcccc}
\hline Parameter & Study site & Mean counts (CFU/mI) & SE mean & StDev & Range (CFU/mI) \\
\hline Total viable counts & & & & & \\
& Ibadan North & $1.56 \times 103$ & 0.74 & 2.33 & $0.01-6.00 \times 10^{3}$ \\
& Ibadan North West & $23.92 \times 103$ & 10.59 & 33.49 & $0.06-100 \times 103$ \\
& Ibadan North East & - & - & - & - \\
& Ibadan South East & $2.10 \times 103$ & 1.27 & 4.01 & $0.02-13 \times 10^{3}$ \\
& Ibadan South west & $1.41 \times 103$ & 0.67 & 2.12 & $0.002-6.5 \times 10^{3}$ \\
Total coliform counts & & & & \\
& & $2.79 \times 10^{3}$ & 1.54 & 4.88 & $0.04-16.0010^{3}$ \\
& Ibadan North & $19.12 \times 10^{3}$ & 5.82 & 18.42 & $2.2-50.00 \times 10^{3}$ \\
& Ibadan North West & $3.72 \times 10^{3}$ & 2.15 & 6.80 & $0.0-17 \times 10^{3}$ \\
& Ibadan North East & $22.52 \times 10^{3}$ & 15.42 & 48.75 & $0.0-160 \times 10^{3}$ \\
& Ibadan South East & $0.95 \times 10^{3}$ & 0.33 & 1.05 & $0.07-3.00 \times 10^{3}$ \\
& Ibadan South West & & & & \\
& & $0.88 \times 103$ & 0.31 & 0.97 & $0.04-2.4 \times 10^{3}$ \\
& Ibadan North & $8.41 \times 103$ & 2.42 & 7.65 & $0.7-22.00 \times 10^{3}$ \\
& Ibadan North West & $2.46 \times 103$ & 1.67 & 5.27 & $0.0-17.00 \times 10^{3}$ \\
& Ibadan North East & $6.64 \times 103$ & 2.32 & 7.33 & $0.0-22.00 \times 10^{3}$ \\
& Ibadan South East & $1.02 \times 103$ & 0.39 & 1.23 & $0.0-3.5 \times 10^{3}$ \\
\hline
\end{tabular}

\section{$\left.0.95 \times 10^{3}\right)($ Table 4$)$}

A total of 65 isolates were obtained with fifty-eight (58) fully identified and grouped into seven genera. The most predominantly isolated organisms are Escherichia coli $(38.5 \%)$, Klebsiella spp (16.9\%), Staphylococcus aureus (13.8\%), and Enterobacter spp (9.2\%) (Table 5).

Table 6 shows the susceptibility of the isolates to common antibiotics. The most active antibiotics were nitrofurantoin (93.6\%) and gentamicin (93.3\%). Streptomycin $(89.9 \%)$, tetracycline $(86.1 \%)$ and nalidixic acid $(79.2 \%)$ were also highly effective. Ampicillin $(37.8 \%)$ was the least potent antibiotics against the pathogens. $14(24.1 \%)$ of the 58 isolates used for the antibiogram were multidrug resistant (resistance to 3 or more antibiotics). E. coli showed 3 multidrug resistance patterns Amp, Col, Nal ,Nit, Cot, Str, Tet; Amp, Cot ,Str ,Tet and Amp ,Cot, Str while Klebsiella spp. showed 2 resistance patterns Amp ,Cot ,Str,Tet and Amp ,Cot, Tet (Table 7).

\section{DISCUSSION}

Water quality issues are health related issues because it 
Table 5. Frequency of isolation of bacteria pathogens from study locations

\begin{tabular}{|c|c|c|c|c|c|c|c|}
\hline Isolate & $\begin{array}{c}\text { Ibadan } \\
\text { North }\end{array}$ & $\begin{array}{c}\text { Ibadan } \\
\text { North-West }\end{array}$ & $\begin{array}{c}\text { Ibadan } \\
\text { North-East }\end{array}$ & $\begin{array}{c}\text { Ibadan } \\
\text { South-East }\end{array}$ & $\begin{array}{c}\text { Ibadan } \\
\text { South-West }\end{array}$ & Total & $\%$ \\
\hline Escherichia coli & 4 & 5 & 6 & 6 & 4 & 25 & 38.5 \\
\hline Klebsiella spp. & 2 & 3 & 4 & 2 & 0 & 11 & 16.9 \\
\hline $\begin{array}{l}\text { Staphylococcus } \\
\text { aureus }\end{array}$ & 2 & 0 & 2 & 4 & 1 & 9 & 13.8 \\
\hline Enterobacter spp. & 1 & 1 & 2 & 1 & 1 & 6 & 9.2 \\
\hline Proteus spp & 0 & 1 & 0 & 1 & 1 & 3 & 4.6 \\
\hline Flavobacterium spp. & 0 & 1 & 0 & 1 & 0 & 2 & 3.1 \\
\hline Unidentified & 2 & 1 & 1 & 1 & 2 & 7 & 10.8 \\
\hline $\begin{array}{l}\text { Pseudomonas } \\
\text { aeruginosa }\end{array}$ & 1 & 0 & 0 & 0 & 1 & 2 & 3.1 \\
\hline Total & 12 & 12 & 15 & 16 & 10 & 65 & 100 \\
\hline
\end{tabular}

Table 6. Susceptibility of isolates to antibiotics (in \%).

\begin{tabular}{lcccccccc}
\hline \multirow{2}{*}{ Isolate } & \multicolumn{8}{c}{ Antibiotics } \\
\cline { 2 - 9 } & AMP & COL & GEN & NAL & NIT & COT & STR & TET \\
\hline Esherichia coli & 50 & 95.5 & 100 & 96 & 68.2 & 68.2 & 77.3 & 90.1 \\
Klebsiella spp. & 55.6 & 100 & 100 & 100 & 100 & 66.7 & 88.9 & 66.7 \\
Enterobacteria spp. & 33.3 & 100 & 100 & 100 & 100 & 66.7 & 83.3 & 100 \\
Proteus spp. & 0 & 0 & 100 & 0 & 100 & 0 & 100 & 100 \\
Pseudomonas aeruginosa & 50 & 50 & 100 & 100 & 100 & 100 & 100 & 100 \\
Staphylococcus aureus & ND & ND & 60 & ND & ND & 100 & ND & 60 \\
Total & 37.8 & 69.1 & 93.3 & 79.2 & 93.6 & 66.9 & 89.9 & 86.1 \\
\hline
\end{tabular}

ND, Not determined.

Table 7. Resistance patterns of isolates.

\begin{tabular}{llc}
\hline Isolate & resistance patterns & Number of isolates with resistance patterns \\
\hline \multirow{2}{*}{ E. coli } & Amp, Col, Nal, Nit, Cot, Str, Tet & 1 \\
& Amp, Cot, Str, Tet & 2 \\
& Amp, Cot, Str, & 5 \\
Klebsiella spp. & Amp, Cot, Str, Tet & 1 \\
& Amp, Cot, Tet & 3 \\
Enterobacteria spp. & Amp, Cot, Str, & 1 \\
Proteus & Amp, Col,Nal, Cot, & 1 \\
Total & & 14 \\
\hline
\end{tabular}

is important in promoting health and reducing global disease burden. This study reports the bacteriological quality of hand dug well- a major source of water supply in Ibadan city. The information from this report would assist in strengthening efforts to improve the quality of water available in the study areas.

Out of the 50 hand dug wells studied, 48 (96\%) were found to be contaminated with both total and faecal coliforms. Total viable bacterial counts $\left(0.002-100 \times 10^{3}\right.$ $\mathrm{CFU} / \mathrm{mL})$, total coliform counts $\left(0-160 \times 10^{3} \mathrm{CFU} / \mathrm{mL}\right)$, 
Table 8. Depth of well-studied in meters.

\begin{tabular}{cccccc}
\hline Sample & Ibadan North & Ibadan North-West & Ibadan North-East & Ibadan South-East & Ibadan South-West \\
\hline 1 & 9.6 & 9.6 & 9.0 & $U$ & 9.0 \\
2 & 8.4 & 8.4 & 12.6 & 15.0 & 7.2 \\
3 & 6.3 & 6.0 & 6.3 & 12.0 & 8.1 \\
4 & 9.0 & 6.6 & 7.2 & 4.5 & 7.2 \\
5 & 5.7 & $U$ & 13.5 & Borehole & 9.0 \\
6 & 7.5 & 4.8 & 12.6 & $U$ & 8.1 \\
7 & 9.0 & $U$ & 9.9 & 11.7 & Borehole \\
8 & 5.4 & 9.0 & 6.3 & 3.60 & 13.5 \\
9 & 10.2 & $U$ & Borehole & 6.3 & 5.7 \\
10 & 8.1 & $U$ & $U$ & 5.4 & 2.1 \\
\hline
\end{tabular}

$\mathrm{U}=$ Unknown.

and fecal coliform $\left(0-22 \times 10^{3} \mathrm{CFU} / \mathrm{mL}\right)$ were high (Table 1). TVBC levels in $40 \%$ of the wells studied exceeded the recommended limit of $1 \times 10^{2} \mathrm{CFU} / \mathrm{ml}$. Water sample from all the wells did not meet the WHO standard set for potable water that recommends total absence of coliform and fecal coliform in $100 \mathrm{ml}$ of drinking water (WHO, 2010).

High TVBC, total coliforms and fecal coliforms counts in water sample from hand dug well have also been reported in recent studies within Nigeria (Osho and Fagade, 2000; Akinyemi et al., 2006; Idowu et al., 2011; Odeyemi et al., 2011) and in other developing countries (Akoachere et al., 2013; Gwimbi, 2011). High counts of indicator bacteria suggest heavy pollution of water with fecal matter. This finding has great implications for public health. Using water from these wells for domestic purposes such as drinking, cooking and washing of fruits and vegetables could predispose users to water borne diseases such as diarhoea, cholera and dysentery. A number of interplaying factors could be responsible for the poor bacterial quality of water from the wells in the study area of this work. The potential reasons for the high presence of microbiological contaminants in the wells may be poor sanitation conditions and practices such as washing laundry near water sources, using dirty containers to collect water from the wells or plunging of bucket directly from the ground into the well. The use of bucket and rope in fetching water from hand dug wells and sitting wells close to sanitary facilities have been reported to contribute significantly to high pollution of wells resulting in deterioration of its water quality (Ayantobo et al., 2012).

The use of electric pump, apart from eliminating contamination from use of bucket, is almost always accompanied with proper sealing of the well. The fecal coliform counts between the locations were significantly different $(p=0.03)$. This may indicate that there is a wide variation in the hygiene behaviours by the household in the study locations.

Another factor that could be of importance to the purity of well water is the depth of the well (Table 8). The fact that no form of microbial contaminant was obtained from the three borehole samples in this study supports the view that very deep wells would yield water with better bacterial purity than shallow wells.

E. coli $(38.5 \%)$ the predominant isolate is a major public health concern as its presence is not only an indication of recent contamination with fecal matter but the possible presence of other dangerous intestinal pathogens. Certain pathogenic strains of the organism such as the enteropathogenic $\mathrm{O} 157: \mathrm{H} 7$ implicated in several out breaks of bloody diarrhea (Geldreich et al., 1992) have been detected in water. Other major pathogens present were enteric organisms such as Klebsiella spp. (16.9\%), Enterobacter spp. (9.2\%), P. aeruginosa (3.1\%), Proteus spp. (4.6\%) and S. aureus $(13.8 \%)$. Their isolation further confirms the contamination of water with fecal material and the possible presence of other waterborne enteric pathogens such as viruses and protozoa. The high number of pathogenic enteric bacteria associated with water samples from the hand dug wells studied contradicts the widely held believe that underground water is relatively free of microorganism and is thus fit for consumption. The most effective of the antibiotics tested was nitrofurantoin $(96.3 \%)$. Other agents with high activity against the isolates are Gentamicin (93.6\%) and Streptomycin $(93.3 \%)$ which is aminoglycosides antibiotics available only as injections. This factor and the relative high cost compared to other antibiotics might have discouraged indiscriminate purchase and misuse. High sensitivity of Gentamicin in this study compares with findings from another study where it has also been reported to be strongly active against bacterial pathogens isolated from well water samples. (Akoachere et al., 2013; Odeyemi et al., 2011).

However, susceptibility to commonly use antibiotics such as ampicillin (37.8\%) and to a lesser extent cotrimoxazole $(66.9 \%)$ was low indicating that most of the isolates are resistant to them. This may not be unconnected 
with indiscriminate use of these drugs without prescription because they are easily accessible. This finding corroborates previous reports of low susceptibility to ampicillin, penicillin and cotrimoxazole in enteric pathogens isolated from water samples (Akoachere et al., 2013; Odeyemi et al., 2011). Seven patterns of multidrug resistance were observed in about $24.1 \%$ of the isolates. This compares with a similar report of about $33.4 \%$ multidrug resistance isolates from well water sample in another study( Akoachere et al., 2013). This high level of multidrug resistance may be an indication of rampant antibiotic misuse among the population due to selfmedication and relative access to the drugs without prescription. The isolation of many of this multidrug resistance isolates from sources that serves as drinking water to so many communities is of public health significance because it can easily serve as reservoir through which antibiotic resistance traits can spread to other bacterial population.

However, the study confirms previous reports of a relatively high prevalence of bacteriological contamination of private wells the world over. Specifically, the study has revealed that majority of the people in Ibadan city who depend on well water for drinking and cooking are at risk of contracting waterborne diseases. There is need for public awareness campaign to encourage routine disinfection of hand dug wells being used as water sources and to educate the general populace about the importance of good sanitary practices. This will reduce the risk of exposure among the population to waterborne infections from the use of well water.

\section{Conflict of interests}

The authors did not declare any conflict of interest.

\section{REFERENCES}

African Development Bank Group (ADB) (2008). Project: urban water supply and sanitation for Oyo and Taraba States. Country: Nigeria. Project appraisal report. Available from: http://www.afdb.org/fileadmin/uploads/afdb/Documents/Project-andOperations/AR\%20Nigeria002En.pdf [accessed 12 November 2014].

Ajayi O, Agbola SB, Olokesusi BF, Wahab B, Taiwo OJ, Gbadegesin M, Taiwo DO, Kolawole O,Muili A, Adeola MA,Olutade OG, Shiji F, Abiola NA (2012). Flood management in an urban setting: a case study of Ibadan Metropolis, In Martins O. Idowu OA, Mbajiorgu CC, Jimoh OD, Oluwasanya GO, editors. Hydrology for disaster management. Nigerian Association of Hydrological Sciences; 65-81. Available

from: http://journal.unaab.edu.ng/index.php/NAHS/article/download/914/88 2 [accessed 21 December, 2014].
Akinyemi OK, Oyefolu AOB, Salu OB, Adewale OA, Fasure AK (2006). Bacterial associated with Tap and well waters in Lagos, Nigeria. East Cent. Afr. J. Surg. 2(1):110-117.

Akoachere JKT, Omam L, Massalla TN (2013). Assessment of the relationship between bacteriological quality of dug-wells, hygiene behaviour and well characteristics in two cholera endemic localities in Douala, Cameroon. BMC Public Health 13:692.

APHA (2006).Standard methods for the Examination of Water and Waste water. American Public Health Association, American Water Works Association and Water Pollution Control Federation. Washington $21^{\text {st }} \mathrm{Ed}$.

Ayantobo OO, Olusanya GO, Idowu OA, Eruola AO (2012). Water quality evaluation of hand-dug wells in Ibadan, Oyo state, Nigeria In Martins O. Idowu OA, Mbajiorgu CC, Jimoh OD, Oluwasanya GO, editors. Hydrology for disaster management. Nigerian Association of Hydrological Sciences. pp. 231-239.

Cowan ST, Steel S (1993). Manual for identification of medical bacterial. Edition by Barrow G I, Felltham R KA. Cambridge University. p. 32.

Geldreich EK, Fox JG, Rice RE, Swerdlow D (1992). Searching for a water supply connection in the Cabool, Missouri Disease outbreak of Escherichia coli O157:H7. Water Res. J. 26:8.

Gwimbi P (2011). The microbial quality of drinking water in Manonyane community: Maseru District (Lesotho). Afr. Health Sci. 11(3):474-480

Idowu AO, Oluremi BB, Odubawo KM (2011). Bacteriological analysis of well water samples in Sagamu, Nigeria. Afr. J. Clin. Exp. Microbiol. 12(2): 86- 91

Ince M, Basir D, Oni OOO, Awe EO, Ogbechie V, Korve K, Adeyinka MA, Olufolabo AA, Ofordu F, Kehinde M(2010). Rapid assessment of drinking-water quality in the Federal Republic of Nigeria: country report of the pilot project implementation in 2004-2005. Geneva \& New York: World Health Organization \& United Nations Children's Fund

Lamikanra A (1999).Essential Microbiology. Amkra Books, $2^{\text {nd }}$ ed. pp. 229-249.

NWSR (2011). Nigerian Water Sector Roadmap. Federal Ministry of Water Resources. pp. 14-15

Odeyemi AT, Akinjogunla OJ, Ojo MA (2011). Bacteriological, physicochemical and mineral studies of water samples from artesian bore-hole, spring and hand dug well located at Oke-Osun, Ikere-Ekiti, Nigeria. Arch. Appl. Sci. Res. 3(3):94-108.

Osho A, Fagade OE (2000). Occurrence of Coliform and Faecal Streptococcus in Ago-Iwoye Well Water. Niger. J. Sci. 34(4):323-329.

Owoeye, JO (2013). Determination of housing and environmental quality for Moniya community in Ibadan, Nigeria. Am. J. Res. Commun. www.usa-journals.com, ISSN: 2325-4076.

Prüss-Üstün A, Bos R, Gore F, Bartram J. (2008) Safer water, better health: costs, benefits and sustainability of interventions to protect and promote health. World Health Organization, Geneva. pp. 11-18. Retrieved

from http://www.whqlibdoc.who.int/publications/2008/9789241596435_eng .pdf

World Health Organization (WHO) (2010). Guidelines for Drinking-water Quality. Recommendation, Geneva, p: 1-6.Retrievefrom http://www.who.int/water_sanitation_health/WHS_WWD2010_guideli nes_2010_6_en. 